Lidia Palumbo \& Heather L. Reid ${ }^{1}$

\section{Wrestling with the Eleatics in Plato's Parmenides}

In his Lives, Diogenes Laertius classifies Platonic dialogues into several types, including gymnastikos and agōnistikos forms of inquiry; the latter are aimed at victory, the former at training the mind. ${ }^{2}$ Although he classifies the Parmenides as neither of these but rather as one for instruction in metaphysics, ${ }^{3}$ we believe that the dialogue illustrates Plato's adaptation of athletic techniques to philosophical inquiry on several levels. To demonstrate this, we will examine the Parmenides's setting, its method, and its theory. On all three levels, we find an important connection between

${ }^{1}$ Lidia Palumbo is professor of ancient philosophy at the Università degli Studi di Napoli Federico II. She is co-editor of the series Philosophike Skepsis, and author of Il non essere e l'apparenza. Sul Sofista di Platone (Napoli 1996), Mimesis: Rappresentazione, teatro e mondo nei dialoghi di Platone e nella Poetica di Aristotle (Napoli 2008), Verba manent, su Platone e il linguaggio (Napoli 2014), and many articles on Plato and Aristotle's Poetics. She is currently working on the theatrical and protreptic dimensions of Platonic texts. Heather L. Reid was introduced in the first essay of the volume. This collaborative essay was completed during her Fulbright residence in Napoli, which was co-sponsored by the Foundation Con il Sud.

2 Diogenes Laertius 3.49: "Of the Platonic dialogues there are two most general types, the one adapted for instruction and the other for inquiry...The dialogue of inquiry also has two main divisions, the one of which aims at training the mind and the other at victory in controversy. Again, the part which aims at training the mind has two subdivisions, the one akin to the midwife's art, the other merely tentative. And that suited to controversy is also subdivided into one part which raises critical objections, and another

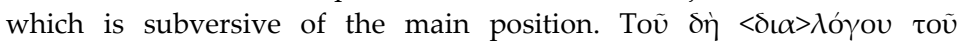

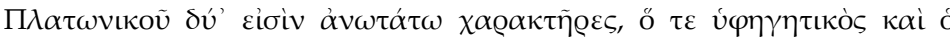

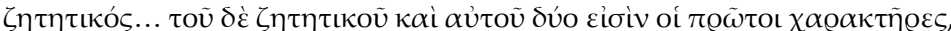

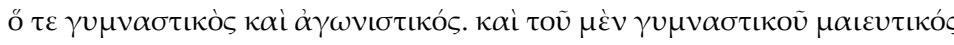

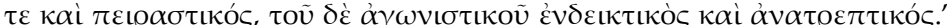
For an analysis, see F. Ferrari, "La nascita del platonismo," in Princep Philosophorum. Platone nell'Occidente tardo-antico, medievale e umanistico, eds. M. Borriello and A.M.Vitale (Roma: Città Nuova, 2016), 13-29.

${ }^{3}$ Diogenes Laertius 3.50. The fact that the Parmenides does not appear in the category of zetetic or gymnastic dialogues in this classification (presumably derived from Middle Platonism) demonstrates only that it was interpreted differently than the others.
Lidia Palumbo \& Heather L. Reid

philosophy and agōn, a specifically gymnastic or training agōn that is aimed not at victory or defeat of one's opponent, but constructively toward the achievement of a philosophical "vision," which is achieved by overcoming the theoretical challenges that philosophers encounter on their path.

This essay interprets the Parmenides agonistically as a constructive contest between Plato's Socrates and the Eleatics of Western Greece. Not only is the dialogue set in the agonistic context of the Panathenaic Games, it features agonistic language, employs an agonistic method, and may even present an agonistic model for participation in the forms. The inspiration for this agonistic motif may be that Parmenides and his student Zeno represent Western Greece, which was a key rival for the mainland at the Olympics and other Panhellenic festivals. This athletic rivalry was complemented by a philosophical rivalry, which is dramatized in the dialogue by pitting a very young (flyweight) Socrates against the Eleatic (heavyweight) Parmenides. Through dialectic, an agonistic form of philosophy attributed to the Eleatics, Plato subjects his theory of forms to a variety of conceptual challenges. This process is described as gymnasia (training) at 135d, and the power of dialectic and philosophy itself are said to depend on it.

The goal of the gymnasia (136c) is to achieve a full view (kyriōs diopsesthai) of the truth. This philosophical "vision" corresponds to the physical fitness achieved through athletic training, and it distinguishes philosophers (lovers of wisdom) from philotheamones (lovers of images) as explained at Republic 475d-476c. Just as trained athletes are able to participate in the contest while spectators merely watch it, philosophers are able to discern intelligible forms through the particulars that participate in them. In the words of the Seventh Letter 341c, it takes prolonged communion (synousia) with a subject to ignite the philosophical light in one's soul. The Parmenides's gymnasia provides an agonistic model for this process, inviting its readers to participate in philosophical training and develop a vison that transcends the material in a way these Eleatic spectators were unable to do. 
Wrestling with the Eleatics in Plato's Parmenides

\section{Setting and Characters}

The Parmenides has an athletic setting and its philosophical characters are compared to athletes. We learn at 127a, that Parmenides and his protégé, Zeno, have come to Athens عis $\Pi \alpha v \alpha \theta \eta \dot{v} v \alpha \_\alpha \dot{\alpha} \mu \varepsilon \gamma \alpha \dot{\alpha} \lambda \alpha$, for the Greater Panathenaic Games. ${ }^{4}$ The Panathenaia was a local religious festival honoring Athena that took place annually. Every fourth year, athletic contests were added and athletes came from all over the Hellenic world to compete for the sacred olive oil contained in Panathenaic prize vases, which can be seen today in museums all over the world. Although these games, like all the "money" games that awarded valuable prizes, were less prestigious than the "crown" games at Olympia, Delphi, Nemea and Isthmia, they grew to become an important Panhellenic event. And just as the Olympic Games provided an opportunity for intellectuals to gather and exchange ideas, the Greater Panathenaia would be a likely occasionperhaps the only likely occasion-upon which Socrates would meet the Eleatic philosophers. Socrates rarely wandered far from Athens, unlike Plato who travelled to Olympia and Western Greece.

The dialogue's narrator, Cephalus (whose name suggests the beginning of something $)^{5}$ says that he has traveled to Athens from Clazomenae in Asia Minor-home of the pre-Socratic philosopher Anaxagoras. ${ }^{6}$ It is not clear whether the Clazomenians were also in

${ }^{4}$ See S. Campese and S. Gastaldi, "Bendidie e Panatenee," in Platone, La Repubblica, vol. I, bk. I, trans. M. Vegetti (Napoli: Bibliopolis, 1998), 109-131.

${ }^{5}$ In this case, the beginning of the Platonic dialogues, since Socrates is younger here than in any other dialogue. On the possibility of ordering Plato's dialogues according to the dramatic context of Socrates's age, see C. H. Zuckert, "Plato's Parmenides: A dramatic Reading," The Review of Metaphysics, 51.4 (1998): 875-906, and C. H. Zuckert, Plato's Philosophers. The Coherence of the Dialogues (Chicago: The University of Chicago Press, 2009). See also M.L. Declos, "Instituer la philosophie: le temps de la succession dans le Parménide de Platon," in C. Darbo-Peschanski (ed.), Constructions du temps dans le monde grec ancien, (Paris: CNRS Éditions, 2000), 223-52.

${ }^{6}$ On the reference to Clazomenae, see F. Forcignanò, Forme, linguaggio, sostanze. Il dibattito sulle idee nell' Academia antica, (Milano-Udine: Mimesis: 2017), 55.
Lidia Palumbo \& Heather L. Reid

town for (a later edition) of the Festival, but it is well-attested by the distribution of Panathenaic amphorae in tombs that delegations from Asia Minor as well as Western Greece attended the Games. In fact, athletes from Sicily and Southern Italy, particularly the city of Croton, were so dominant that a proverb claimed, "The last of the Crotonites is the first of the rest of the Greeks."7 Croton, of course, is also the adopted home of Pythagoras, ${ }^{8}$ who very likely had a hand in its athletes' success, and certainly had a major influence on Western Greek thinkers including Empedocles, Parmenides, and Zeno. That Plato was aware of the athletic side of Pythagoreanism is suggested by his decision to set up a school in the Academy gymnasium ${ }^{9}$ upon returning from a voyage to Syracuse and Taranto, where he met the Pythagorean Archytas ${ }^{10}$ who, by one account, rescued the Athenian from slavery after a later voyage.

The point is that the athletic rivalry between Mainland and Western Greeks was accompanied in Plato's mind by a philosophical rivalry. Furthermore, as a former wrestler, ${ }^{11}$ Plato would have understood this rivalry as a constructive one in which good competition serves to improve the competitors. By pitting a very young Socrates against the venerable Eleatic Parmenides in dialectic (a form of inquiry attributed to Zeno), ${ }^{12}$ Plato subjects his theory of forms to a variety of conceptual challenges in the effort to make it stronger. The dialogue's participants are also described in athletic terms. Parmenides compliments Socrates for his hormē

${ }^{7}$ Strabo, Geographia 6.1.12.

${ }^{8}$ For a discussion of Pythagoras's influence on athletics see Heather L. Reid, "Plato the Gymnasiarch," in $\Phi I \Lambda E \Lambda \Lambda H N$ : Essays for Stephen G. Miller, eds. D. Katsonopoulou \& E. Partida, Athens: The Helike Society, 171-186, p 173. ${ }^{9}$ Diogenes Laertius, 3.7.

${ }^{10}$ Diogenes Laertius 3.21-22.

${ }^{11}$ Diogenes Laertius, 3.1.4.

${ }^{12}$ According to Diogenes Laertius 8.2.57, Aristotle in his Sophist calls Empedocles the inventor of rhetoric and Zeno of dialectic. "

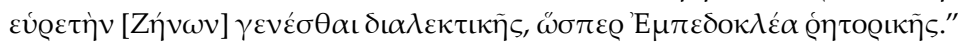


Wrestling with the Eleatics in Plato's Parmenides toward argument ${ }^{13}$ - an athletic word that suggests the eagerness of a runner or racehorse bursting from the starting gate. Zeno, meanwhile, confesses to writing his book out of "competitive spirit" (philonikia), a vice that Plato takes to be characteristic of athletes and sophists. ${ }^{14}$ It is worth noting, as well, that Plato himself is engaged in the parallel act of writing a book to competitively defend his theory of forms.

Finally, Parmenides himself is compared with the aging racehorse in a song from the Western Greek poet, Ibycus:

I am obliged to go along with you. And yet I feel like the horse in the poem of Ibycus. Ibycus compares himself to a horse-a champion but no longer young, on the point of drawing a chariot in a race and trembling at what experience tells him is about to happen-and says that he himself, old man that he is, is being forced against his will to compete in Love's game. I too, when I think back, feel a good deal of anxiety as to how at my age I am to make my way across such a vast and formidable sea of words.

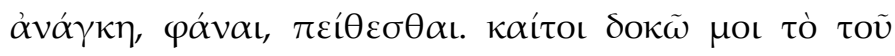

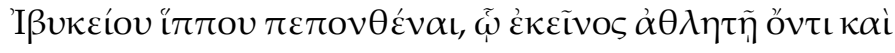

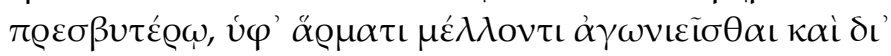

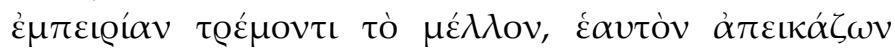

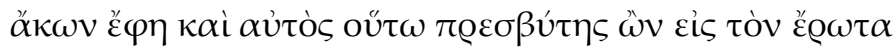

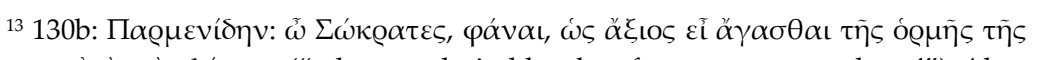

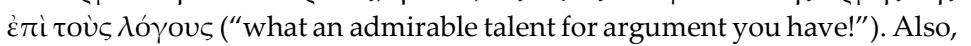

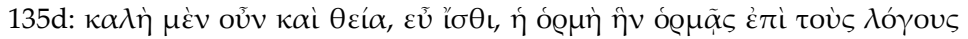
(Your impulse towards dialectic is noble and divine).

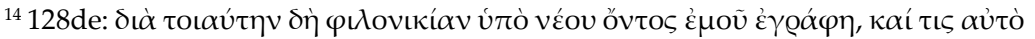

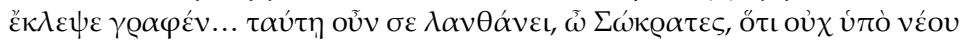
$\varphi$ that competitive spirit, I wrote the book when I was a young man. [...] So in this respect, I think you missed the point, Socrates, you think it was written not out of a young man's competitiveness but out of a mature man's vainglory." Both philonikia and philotimia are considered by Plato to be vices characteristic of athletes and sophists. See M. Tabak, Plato's Parmenides Reconsidered, (New York: Palgrave Macmillan, 2015), 31-2.
Lidia Palumbo \& Heather L. Reid

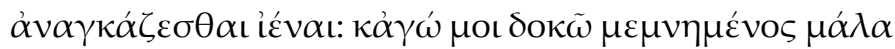

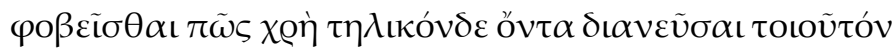

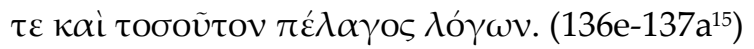

By $137 \mathrm{~b}$, however, Parmenides has agreed "to play the strenuous

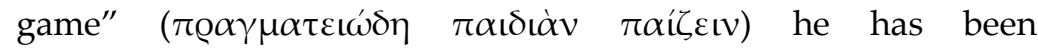
recommending to Socrates. ${ }^{16}$ After all, he observes, they are by themselves - no one is watching.

\section{Method: the "Gymnasia"}

At 135c, the "game" in question is actually called "gymnasia" (training) and Parmenides tells Socrates that nothing less than the power of dialectic and the future of philosophy depend on it. ${ }^{17}$ Dialectic, as we said, was a form of inquiry attributed by Aristotle to Zeno of Elea. ${ }^{18}$ The method demonstrated by Parmenides in the dialogue is certainly an example of Eleatic dialectic. ${ }^{19}$ But why, apart from its affinity with athletic contest, is this dialectic called gymnasia? The first hint comes from the aforementioned comments about it taking place in private. ${ }^{20}$ At 136de, Zeno says it would not

${ }^{15}$ Unless otherwise stated, all English translations of Plato are taken from John Cooper, ed., Plato: Complete Works (Indianapolis: Hackett, 1997).

${ }^{16}$ It is significant that Parmenides uses the terms paidia/paizein here (to play a game), which suggests the sophists' abuse of philosophical tools such as dialectic. In our interpretation, the Eleatics are presented in the Parmenides as practitioners of a sophistical dialectic, whereas Socrates, here at the beginning of his career, and thanks to the training that he is beginning to undergo, is capable of authentically philosophical dialectic. On sophistry as a game, see Plato, Sophist, 234b-235a.

${ }_{17} 135$ c: “'In this way he [who does not allow for forms] will destroy the power of dialectic entirely. But I think you are only too well aware of that./ 'What you say is true,' Socrates said./ 'What then will you do about philosophy? Where

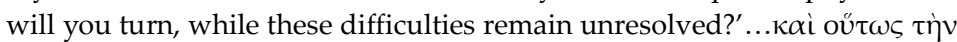

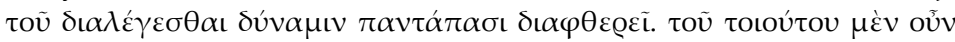

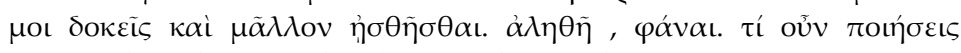

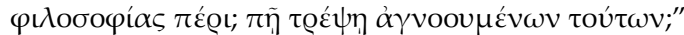

18 See $\mathrm{n} .12$ above.

${ }^{19}$ On the Eleatic method in Plato's Parmenides, see Samuel Scolnicov, Plato's Parmenides (Berkeley: University of California Press, 2003).

${ }^{20}$ The lack of spectators transforms the dialectic from a public agōn (the prefix agindicates a public gathering) into a private gymnasia (training exercise). 
Wrestling with the Eleatics in Plato's Parmenides

be appropriate to ask Parmenides to perform the gymnasia in public:

...it's not fitting, especially for a man his age, to engage in such a discussion in front of a crowd. Ordinary people don't know that without this comprehensive and circuitous treatment we cannot hit upon the truth and gain insight.

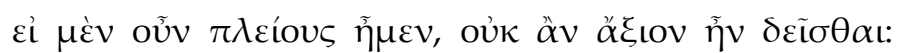

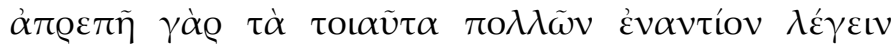

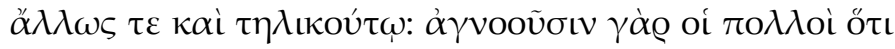

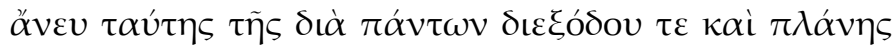

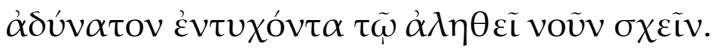

Just as athletes train privately in the gymnasium and compete publically in the games, philosophers need to train in private before they perform in public. ${ }^{21}$ And once a champion like Parmenides is past his prime, his experience is of special value in training younger competitors, such as Socrates..$^{22}$ By Plato's time,

${ }^{21}$ A similar point about training in private before performing in public is made at Gorgias 514e: "by Heaven, Callicles, would it not in truth be ridiculous that men should descend to such folly that, before having plenty of private practice, sometimes with indifferent results, sometimes with success, and so getting adequate training in the art, they should, as the saying is, try to learn pottery by starting on a wine-jar, and start public practice themselves and invite others of their like to do so? Do you not think it would be mere folly

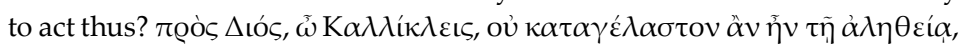

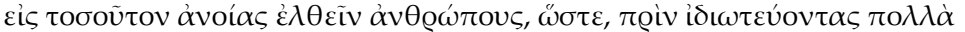

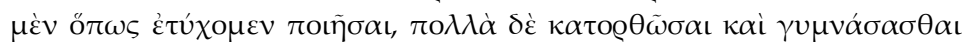

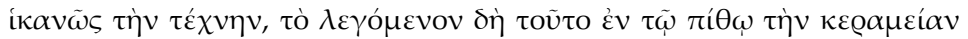

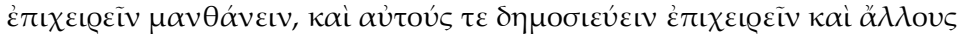

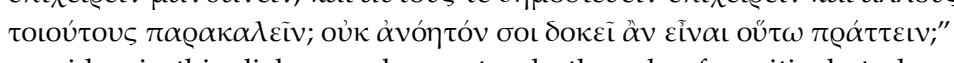

22 Parmenides, in this dialogue, plays not only the role of a critic, but also a defender of the Theory of Forms. The two roles are unified in the figure of the objector (ó $\alpha \mu \varphi \iota \sigma \beta \eta \tau \tilde{\omega} v, 133 b 8$, cfr. 135a), in which he poses questions to train Socrates, who has to respond and defend the Theory of Forms. On the role of the respondent, see M.L. Kakkuri-Knuuttila, "The Role of the Respondent in Plato and Aristotle," in The Development of Dialectic from Plato
Lidia Palumbo \& Heather L. Reid

the training of both athletes and philosophers actually took place in the gymnasium and only the former competed in the Games. Parmenides, however, may well have performed his philosophical poem competitively during his prime. Indeed, the rhetorical contests that Plato derides may have descended from competition among serious philosophers like Parmenides and Empedocles. ${ }^{23}$

In any case, the gymnasia demonstrated in the Parmenides has the flavor of a master sparring privately with his students, as we see the mature Socrates doing in such dialogues as Charmides, Lysis, and Theaetetus-all of which are set in palaistrai or gymnasia. ${ }^{24}$ Indeed, the Theaetetus echoes several of the Parmenides's gymnastic themes. For example, Theodorus is reluctant to enter the "contest" (helkein pros to gymnàsion) and asks Socrates to (labe) "get a hold on" Theaetetus in the argument (162ab); also, Theaetetus agrees to wrestle only upon the agreement that Socrates and Theodorus will "put him upright" (epanorthō) if he falls (146c). Helping your opponent to his feet is a common feature of combat sports training. This atmosphere of friendly competition is compounded in Parmenides by Zeno's and Parmenides's obvious delight in Socrates's challenge to their ideas at 130a; if the atmosphere were one of philonikia, such criticism might draw contempt. Although some scholars see the defeat either of Socrates or Parmenides in the dialectic, ${ }^{25}$ the very fact that

to Aristotle, ed. Jakob L. Fink (Cambridge: Cambridge University Press, 2012), 62-90.

${ }^{23}$ See N. Benzi, Philosophy in Verse: Competition and Early Greek Philosophical Thought, thesis, Durham University. 2016 http://etheses.dur.ac.uk/11568/, 181-186.

${ }^{24}$ L. Coventry, "The Role of the Interlocutor in Plato's Dialogues, Theory and Practice," in Characterization and Individuality in Greek Literature, ed. Ch. Pelling (Oxford: Clarendon Press, 1990), 174-196.

${ }^{25}$ We do not believe that the Parmenides depicts a dialectical defeat of Socrates, but rather shows how Parmenides's objections to his theory are ultimately inconsistent. For another interpretation of the text from this perspective, see F. Ferrari, Platone, Parmenide (Milano: Bur, 2004); A. Graeser, "Parmenides in Plato's Parmenides," in Issues in the Philosophy of Language. Past and Present (Bern: Peter Lang Publishing, 1999), 43-56; M. Tabak, Plato's Parmenides 
Wrestling with the Eleatics in Plato's Parmenides it is unclear who "wins" illustrates that this gymnasia is a form of mutually-beneficial training rather than a winner-take-all contest. ${ }^{26}$

The Parmenides's dialectic is called gymnasia, above all, because it is a form of preparation. Let's go back to where Parmenides asks Socrates what he will do about philosophy if his questions about the forms remain unresolved. "I don't think I have anything clearly in view," replies the young Socrates, "at least not at present" (135c). Parmenides responds:

Socrates, that's because you are trying to mark off something beautiful, and just, and good, and each one of the forms, too soon...[prin gymnasthēnai] before you have been properly trained. I noticed that the other day too, as I listened to you conversing with Aristotle here. The impulse [hormē] you bring to argument is noble and divine, make no mistake about it. But while you are still young put your back into it and get more training [gymnasai] through something people think uselesswhat the crowd call idle talk. Otherwise the truth will escape you.

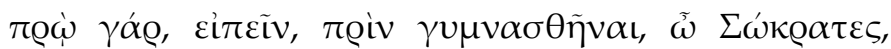

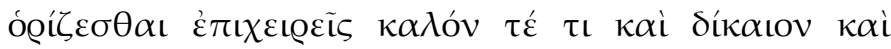

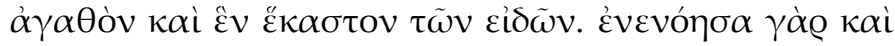

Reconsidered (New York: Palgrave, 2015), 29: "Part I is clearly a satirical display of various objections to the theory of Forms, which are invalid, non sequitur reactions to the theory of Forms that smack of sophistry."

${ }^{26}$ The gymnasia benefits Socrates (or the critical reader of Socrates) by subjecting the theory of forms to the Eleatics' critical examination, so he can overcome some important theoretical challenges (attributable partly to his young age). But it also benefits Parmenides (or the critical reader of Parmenides), by revealing certain materialistic biases in the Eleatic criticism of Socrates. On this last point, see F. Ferrari, “Equiparazionismo ontologico e deduttivismo: l'eredità di Parmenide nella gymnasia del Parmenide," in Il quinto secolo. Studi di filosofia antica in onore di Livio Rossetti, eds. S. Giombini and F. Marcacci (Aguaplano: Officina del libro, Passignano, 2010), 357-368. On the text's instruction of the reader, see A.K. Cotton, Platonic Dialogue and the Education of the Reader (Oxford/New York: Oxford University Press, 2014).
Lidia Palumbo \& Heather L. Reid

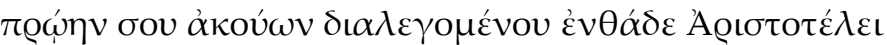

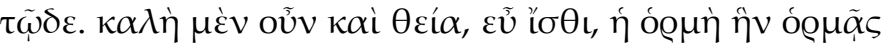

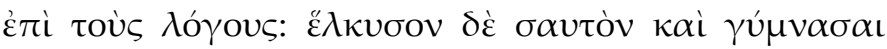

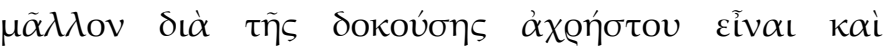

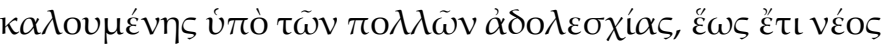

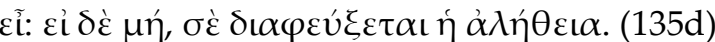

The image of truth "escaping" the hold of a wrestler is unavoidable here. Young Socrates wants to learn the old champion's technique.

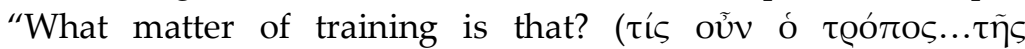
$\left.\gamma u \mu v \alpha \sigma i \alpha \varsigma_{;}\right), "$ he asks (135d).

The method that Parmenides describes is a special type of dialectic-a kind of round-robin reductio. Reductio ad absurdum works by hypothesizing the opposite of what you want to prove and then showing that the consequences are absurd. Standard dialectic envisions an objector who challenges each hypothesisnot unlike a wrestling match. What Parmenides proposes is a comprehensive system that subjects a hypothesis and its opposite to a series of reductio challenges, then analyzes the consequences. ${ }^{27}$ Ancient wrestling tournaments were single elimination, with wrestlers drawing lots to determine matches and the winners advancing until a victor was determined. ${ }^{28}$ Parmenides's method looks more like a round-robin tournament, in which each competitor faces every other competitor-as in the group play phase of the FIFA World Cup..$^{29}$ The round-robin method is less efficient at picking winners, but it has the advantage of revealing each contestant's individual strengths and weaknesses. It makes sense, furthermore, to prepare for a competition, in which one never knows exactly who one will be wrestling, by testing oneself against everyone else in the gymnasium who can provide an

${ }^{27}$ For a summary of the structure of the gymnasia, see F. Fronterotta, Guida alla lettura del Parmenide di Platone (Roma-Bari, Laterza, 1998).

${ }^{28}$ Michael B. Poliakoff, Combat Sports in the Ancient World (Yale University Press, 1987), 22.

${ }^{29}$ In the gymnasia, not only does the one confront the many, and the many-each alone and all together-confront the one, but it also happens that Socrates confronts Parmenides and Zeno, and then each of them separately. 
Wrestling with the Eleatics in Plato's Parmenides appropriate challenge. This is the kind of "comprehensive and

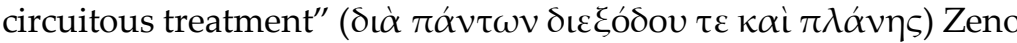
describes at 136e. So Parmenides's gymnasia is private, cooperative, comprehensive preparation, akin to that undertaken in traditional gymnasia by athletes preparing for the Games. But what, exactly, is the philosopher training for?

\section{Theory: Philosophical Vision}

The theory and method of the Parmenides come together in the idea of a philosophical vision. The dialogue's theoretical background holds that material particulars participate in intelligible forms without being identical to them or completely separate. At 136c, Parmenides says to Socrates that he must complete the gymnasia in order to "achieve a full view (kyrioss diopsesthai) of truth." The goal of the philosopher's gymnasia, then, is to develop the "vision" by which sensible objects can be distinguished from intelligible forms, and the latter discerned through the former's participation in them. In other words, the gymnastic method cultivates a capacity to see things philosophically just as athletic exercises cultivate the capacity to wrestle competitively. Specifically, the philosopher is able to look beyond particulars as they show up superficially in our sense-data and see through to the ideals in which they participate. This is because the round-robin reductio, discussed above, forces us to imagine and consider all of the different consequences of each hypothesis. The challenge provided by opposing hypotheses, which is the basic method of dialectic, pushes us to transcend the limitations of material reality (135e) and to consider what exists only in the intelligible realm. In addition, by forcing us to consider what would be if things were opposite, it renders the invisible visible, considers the possibility of the apparently impossible, and in short evokes that sense of wonder characteristic of philosophers (not to mention the sense of possibility characteristic of sport). ${ }^{30}$

Such a concept of philosophical vision is illustrated in Republic $\mathrm{V}$, appropriately enough with a contrast between spectators

${ }^{30}$ See L. Palumbo, “La meravigliosa struttura dell' 'altrimenti'. Una lettura del Parmenide di Platone," Archivio di Storia della Cultura - Anno XXXIII-2020.
Lidia Palumbo \& Heather L. Reid

(philotheamones) who love to watch festivals, and philosophers who "love the sight of truth." At 476b, spectators are described as those able to see the many beautiful things but not the beautiful itself. ${ }^{31}$ A philosopher, by contrast,

believes in the beautiful itself, can see both it and the things that participate in it and doesn't believe that the participants are it or that it itself is the participants.

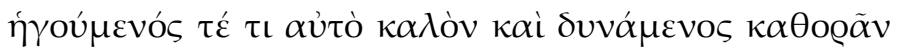

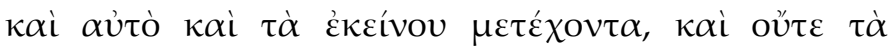

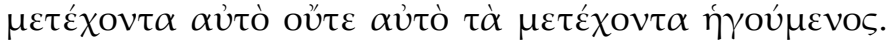
$(476 \mathrm{~cd})$

What is interesting, maybe even ironic, ${ }^{32}$ is that the heavyweight philosopher Parmenides himself seems to lack such vision because the mistake he makes in the dialogue is precisely to fail to distinguish between forms and particulars, ${ }^{33}$ immaterial and material. ${ }^{34}$ For example, when Socrates tries to explain the relation

${ }^{31}$ Republic 476b: "The lovers of sights and sounds like beautiful sounds, colors, shapes, and everything fashioned out of them, but their thought is unable to see and embrace the nature of the beautiful itself. $\varphi \iota \lambda \eta \dot{\kappa} \kappa о\llcorner\kappa \alpha i$

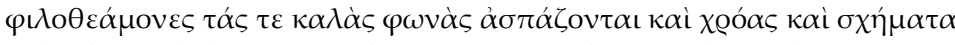

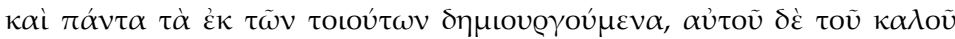

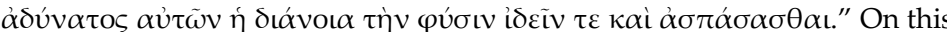
passage, see F. Ferrari, "Teoria delle idee e ontologia," in Platone, Repubblica vol. iv, bk. 5, ed. M. Vegetti, (Napoli: Bibliopolis, 2000), 365-91.

${ }^{32}$ G. A. Press, Plato: A Guide for the Perplexed (London-New York: Continuum, 2007), 70 writes: "If they [Plato's dialogues] are attempts to communicate theories, concepts and doctrines that are Plato's own, they do not do so directly, but only indirectly through the mediation of [...] literary and dramatic machinery."

${ }^{33}$ The gymnasia, the lengthy discourse proposed by Parmenides in the last part of the dialogue, is the Platonic way of demonstrating the absurd, selfcontradictory, and therefore ridiculous conclusions arrived at by a sophistical Eleatism, which dialectically questions the ontological difference between forms and particulars.

${ }^{34}$ This materialistic aspect of the Eleatic argument is crucial. It is evident in the entire Eleatic perspective, which conceives the relationship between the forms and particulars, or between the one and the many, in terms of a 
Wrestling with the Eleatics in Plato's Parmenides between form and particular using the metaphor of the light of day, Parmenides counters with the materialistic example of a sail (131bc). ${ }^{35}$ The Eleatic is presented as hopelessly attached to the material world.

Like several Platonic dialogues, the Parmenides not only discusses dialectic, it attempts to engage the reader in practicing it. On Plato's view, philosophy requires active participation. Just as the wrestler improves through engagement with other wrestlers, the philosopher improves through engagement with other philosophers, and it is through this dialectical wrestling with each other that they both move closer to the ideal. ${ }^{36}$ Socrates's refusal to write at all and Plato's insistence on writing only dialogues are evidence for this belief. The Seventh Letter, meanwhile, states it specifically:

Unlike other sciences, [philosophy] can in no way be communicated by means of words. On the contrary, it is only through a prolonged communion (synousia) with the subject, by living with it, that, like a light that is kindled by a flickering flame, it begins to suddenly nourish itself within one's soul.

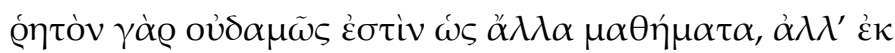

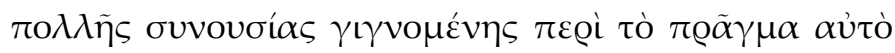

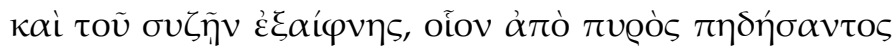

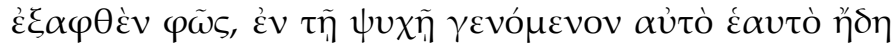

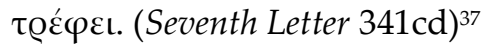

We believe that Plato primarily imagined this communion with the subject as the kind of private dialectic modeled on athletic training

combination of two elements in space, or in terms of a temporal conjunction of two material entities.

${ }^{35}$ See Ferrari, Platone, Parmenide, 212, n. 45

36 This model can be observed in Lysis, see H. Reid, "The Art of Teaching Philosophy in Plato's Lysis," Skepsis XVI i-ii (2005): 278-287.

${ }^{37}$ Translation by Jonah Radding from H. Reid and M. Ralkowski, eds. Plato at Syracuse: Essays on Plato in Western Greece with a New Translation of the Seventh Letter by Jonah Radding (Parnassos Press, 2019). Even if Plato is not the author of the letter, it is widely believed to express the philosopher's views.
Lidia Palumbo \& Heather L. Reid

that is called gymnasia in the Parmenides. And we argue that the dialogue itself is set up to engage readers in that gymnasia, in particular to get them to think beyond materialism, here represented by Parmenides. A full analysis of the philosophical problems presented by the dialectic must be left for another time, however.

\section{Conclusion}

It has been our purpose to show that Plato's Parmenides can be interpreted agonistically as a constructive contest between Eleatic and Athenian philosophers. By setting the dialogue at the Panathenaic Games and using athletic language to describe its participants, Plato uses the athletic rivalry between Mainland and Western Greeks to highlight a parallel philosophical rivalry. As a former wrestler, Plato would envision this rivalry as constructive, and imagine the dialectical method, here called gymnasia, as a kind of philosophical training. It is a private, comprehensive, and challenging preparation designed to reveal the weaknesses in hypotheses, but also to develop the kind of "vision" described in Republic V, which distinguishes the philosopher from the mere spectator. This philosophical gymnasia resembles a round-robin training exercise in which the reader is called to participate. In Republic III, Socrates states that gymnastike primarily benefits the soul (psychē, 410c), while the Parmenides offers a philosophical gymnasium in which all souls are invited to train. 